\title{
KEMAMPUAN PEMBENTUKAN SLIME PADA Staphylococcus epidermidis, Staphylococcus aureus, MRSA DAN Escherichia coli
}

\author{
Rini Purbowati, Emillia Devi Dwi Rianti, Fuad Ama \\ Bagian Biomedik Fakultas Kedokteran \\ Universitas Wijaya Kusuma Surabaya \\ email: purbowatirini@gmail.com,mbak.devi@gmail.com, fuad.ama2010@gmail.com
}

Diterima 3 Mei 2017 disetujui 5 Juni 2017

\begin{abstract}
Biofilms are an organized community of bacteria, accumulating in polymeric metrics (EPS) or also called slimes, which are produced by the bacteria itself and are able to attach to both life and non-living surfaces. Infections accompanied by biofilm formation are difficult to treat. S. aureus and S. epidermidis is the causative agent of infection in medical implants and nosocomial infections in worldwide. Congo Red Agar (CRA) method as a fairly cheap and easy phenotypic method with evaluation criteria is based on visual analysis of colony color which growing on agar medium. This study aims to identify and analyze the ability of slime formation in S. epidermidis, S. aureus, MRSA and E. coli. The test was performed by planting S. epidermidis, S. aureus (MSSA 1 and MSSA 2), MRSA 1 and E. coli (S4 and S55) which have been rejuvenated to CRA medium in petri dish by streak 4 areas. Incubating for 24 hours at $37{ }^{\circ} \mathrm{C}$ under aerobic conditions. Interpretation of the results according to the following provisions: strains produce dark, black, and black colored colonies considered to produce slime, whereas red and reddish colonies are classified as not producing slimes. The conclusions of this study were isolates of $S$. epidermidis, $S$. aureus and MRSA known to be able to form slime while E. coli isolate showed varied results.
\end{abstract}

Keywords : Slime, S.epidermidis, S.aureus, MRSA, and E. coli

\section{PENDAHULUAN}

Biofilm adalah komunitas bakteri yang terorganisasi, terakumulasi dalam metriks polimer yang diproduksi oleh bakteri itu sendiri dan mampu melekat pada permukaan hidup maupun tak hidup (Moghadam, Pourmand and Aminharati, 2014). Dalam biofilm, sel tumbuh dalam bentuk gumpalan multiseluler yang terbungkus matriks ekstraselular atau Extracellular Polymeric Substances (EPS) yang dihasilkan oleh bakteri itu sendiri (Daniel Lo'pez, Hera Vlamakis and Roberto Kolter, 2010). EPS adalah molekul yang memiliki berbagai ukuran, komposisi, dan sifat kimia yang dihasilkan dan disekresikan oleh bakteri dan mikroorganisme lainnya, dan berkontribusi pada kemampuan adaptasi, ketahanan dan fungsional sel pada lingkungan. Secara definisi EPS bersinonim dengan kapsul, eksopolimer, sekresi mikroba dan Slime (Decho, 2011). Eksopolisakarida dihasilkan oleh bakteri Gram negatif dan Gram positif. Struktur fisik eksopolisakarida berupa kapsul sampai dengan dinding sel slime masif yang terbentuk di luar membran sel bakteri (Steinmetz et al.,1995)

Semua biofilm mengandung matriks ekstraselular yang melekatkan sel satu dengan sel lainnya. Matriks ini sering kali terdiri dari biopolimer polisakarida bersama 
dengan komponen lain seperti protein atau DNA. Sifat dari matriks eksopolisakarida sangat bervariasi tergantung pada kondisi pertumbuhan, media dan substrat (Daniel Lo'pez, Hera Vlamakis, and Roberto Kolter, 2010). Produksi biofilm bergantung pada kemampuan bakteri untuk menempel pada permukaan abiotik maupun biotik, berproliferasi dan menghasilkan matriks ekstraselular, yang utamanya terbentuk dari Polysaccharide Intercellular Adhesion (PIA) pada $S$. aureus (Klein et al., 2015).

Pembentukan biofilm terjadi dalam empat tahap antara lain adhesi atau perlekatan, perkembangan awal struktur biofilm, pematangan dan dispersi sel dari biofilm ke lingkungan sekitarnya dan pada akhirnya kembali ke keadaan planktonik. Untuk dapat membentuk biofilm diperlukan keterlibatan beberapa faktor permukaan sel seperti flagella dan motilitas, fimbriae, protein autotransporter, curli fimbrie, pilus konjugatif, dan produksi eksopolisakarida. Motilitas (perpindahan) pada $E$. coli secara umum karena adanya disebabkan beberapa flagella peritrikus. Motilitas terlibat dalam proses kolonisasi pada organisme atau organ target inang dan memicu timbulnya kontak antara sel dengan permukaan (Tenke et al., 2011).

Staphylococcus aureus bersama dengan Staphylococcus epidermidis merupakan mikroorganisme komersal yang tidak berbahaya, namun sekarang ini secara global dipandang sebagai patogen oportunistik yang penting terkait dengan infeksi yang berbeda. Mereka menempati urutan pertama di antara agen penyebab infeksi antara lain infeksi implan medis dan infeksi nosokomial di seluruh dunia, dan terutama di negara-negara berkembang (Daniela Chessa, Giulia Ganau, dan Vittorio Mazzarello, 2015).

S.epidermidis pada umumnya dapat diisolasi dari epitel manusia dan berkoloni pada bagian aksila, kepala dan rongga hidung. Bakteri ini merupakan bagian dari mikroflora epitel manusia dan oleh karena itu memiliki hubungan yang dekat dengan hospes, namun $S$. epidermidis telah muncul sebagai strain patogen yang menyebabkan berbagai infeksi berbeda (Daniela Chessa, Giulia Ganau, dan Vittorio Mazzarello, 2015). S. epidermidis merupakan Staphylococcus dengan sifat biokimia koagulase negatif yang paling umum atau Coagulase-Negative Staphylococcus (CNS), yang dipisahkan dari Staphylococcus koagulase positif seperti $S$. aureus berdasarkan kurangnya enzim koagulase yang dimilikinya. $S$. epidermidis sering ditemukan pada infeksi yang berkaitan dengan rumah sakit (infeksi nosokomial), terutama bakteremia yang berhubungan dengan penggunaan kateter dan infeksi kardiovaskular. Patogenesis infeksi ini tergantung pada kemampuan strain S. epidermidis untuk menempel di permukaan melalui produksi eksopolimer yang membentuk struktur multilayer yang dikenal sebagai biofilm (Kaiser et al., 2013)

S. aureus merupakan bakteri Gram positif, patogen utama pada manusia dan hewan, menyebabkan berbagai macam penyakit mulai dari infeksi kulit dan jaringan lunak hingga penyakit invasif yang mengancam jiwa (Daniela Chessa, Giulia Ganau, dan Vittorio Mazzarello, 2015). S. aureus merupakan bakteri komensal sekaligus bakteri patogen pada manusia. Sekitar 30\% dari populasi manusia dapat dijadikan sarana untuk kolonisasi bakteri $S$. aureus. Oleh karena itu $S$. aureus menjadi penyebab tersering pada bakteremia dan infeksi endokarditis serta osteoartikular, infeksi kulit dan jaringan lunak, pleuropulmonari, dan infeksi yang terkait penggunaan implan pada peralatan kesehatan (Tong et al., 2015). Patogenesis strain $S$. aureus disebabkan oleh efek gabungan dari faktor ekstraselular dan toksin, bersama dengan sifat invasif strain seperti perlekatan, pembentukan biofilm, dan ketahanan terhadap fagositosis. Beberapa puluh tahun 
terakhir muncul strain dari $S$. aureus yang resisten terhadap antibiotik jenis tertentu yaitu Meticillin Resistant Staphylococcus. aureus (MRSA) (Daniela Chessa, Giulia Ganau, dan Vittorio Mazzarello, 2015).

Escherichia coli merupakan bakteri Gram-negatif, oksidase-negatif, berbentuk batang dari famili Enterobacteriaceae. Bakteri ini mampu tumbuh baik secara aerobik dan anaerobik, hidup pada suhu $37^{\circ} \mathrm{C}$, dan bisa juga nonmotile atau motil, dengan flagella peritrichous (Croxen et al., 2013). E. coli dikenal sebagai bakteri komensal, ditemukan pada mikroflora usus dari berbagai hewan termasuk manusia, tidak semua dari strain ini tidak berbahaya, namun ada beberapa strain dapat menyebabkan penyakit yang berbahaya dan kadang fatal pada manusia dan juga mamalia dan kelompok burung. Strain patogenik dibagi menjadi beberapa yaitu strain patogen pada intestinal mampu menyebabkan diare serta E. coli ekstraintestinal (ExPEC) mampu menyebabkan berbagai infeksi pada manusia dan hewan termasuk infeksi saluran kemih (ISK), meningitis dan septikemia. Sistitis dan pylonefritis yang dapat menyebabkan urosepsis disebabkan oleh Uropathogenic E. coli (UPEC) yang merupakan penyebab sekitar $80 \%$ dari 130-175 juta ISK pada manusia (Jafari, MM Aslani dan S. Bouzari, 2012).

Patogen utama penyebab ISK pada wanita adalah $E$. coli, yang bertanggung jawab terhadap sekitar $80 \%$ dari semua kejadian ISK (Echols et al., 1999). E. coli yang mampu tumbuh dan berkolonisasi pada saluran urogenital dikenal sebagai UPEC (Uropathogenic Escherichia coli). UPEC memiliki beberapa faktor virulensi yang memungkinkan mereka untuk dapat berkolonisasi pada mukosa uroepitelium inang, melukai dan menyerang jaringan inang, melumpuhkan mekanisme pertahanan inang, memicu respons inflamasi inang dan akhirnya berlanjut menyebabkan infeksi mulai dari saluran kemih bagian bawah hingga rongga ginjal dan jaringan ginjal (Tenke, et al., 2011).

Infeksi yang disertai dengan pembentukan biofilm menjadi masalah yang besar, karena sulit ditangani secara efektif oleh sistem kekebalan tubuh inang dan tahan terhadap pengobatan dengan antimikroba. Mekanisme perlindungan tersebut dianggap menghalangi penyerapan dan penetrasi antibiotik melalui matriks biofilm (Cavaliere, et al., 2014). Biofilm diketahui terlibat dalam berbegai macam infeksi mikroba dalam tubuh, Diperkirakan hampir 80\% dari semua infeksi (Ghafourian et al., 2013).

Karakterisasi biofilm secara in vitro yang sederhana berperan penting untuk menjawab pertanyaan dasar tentang pembentukan fisiologi dan arsitektur biofilm. Model biofilm secara in vitro memiliki sejumlah keunggulan seperti biaya murah, kemudahan pengaturan kondisi eksperimental, dan kemampuan untuk menganalisis lapisan biofilm yang terbentuk juga lebih tinggi (Lebeaux, et al., 2013). Salah satu metode in vitro yang digunakan untuk mendeteksi pembentukan slime sebagai komponen dari biofilm adalah metode Congo Red Agar (CRA). Metode ini dikembangkan oleh Freeman et al., 1989 sebagai metode fenotipik menggunakan media BHIA (Brain Heart Infusion Agar) yang disuplemen dengan sukrosa dan ditambahkan pewarna merah Congo. Metode ini cukup murah dan mudah dilakukan dan kriteria evaluasi didasarkan pada analisis visual warna koloni yang tumbuh pada media agar (Kaiser et al., 2013).

Penelitian ini bertujuan untuk mengidentifikasi dan menganalisa kemampuan pembentukan slime pada isolat Staphylococcus epidermidis, Staphylococcus aureus, MRSA dan E. coli, sehingga memberikan data awal tentang perbandingan kemampuan pembentukan slime sebagai komponen dalam biofilm pada ketiga strain bakteri ini. 


\section{METODE}

Bahan penelitian antara lain: Isolat bakteri klinik yaitu $S$. epidermidis, $S$. aureus atau Meticillin Sensitive Staphylococcus. aureus (MSSA) yaitu MSSA 1 dan MSSA 2, MRSA 1 dan E. coli, media NA (Nutrient Agar), media LB, sukrosa, bubuk agar dan pewarna merah Congo. Alat dalam penelitian ini: Erlenmeyer $500 \mathrm{~mL}$, tabung reaksi, cawan petri, jarum ose dan api bunsen.

Tahapan-Tahapan Penelitian ini antara lain.

\section{Pembuatan Media Congo Red}

Media CRA (Congo Red Agar) dibuat dengan komposisi media sebagai berikut: media LB (30 g/L), sukrosa (36 $\mathrm{g} / \mathrm{L})$, bubuk agar (18 g/L) dan pewarna merah Congo $(0,8 \mathrm{~g} / \mathrm{L})$. Media LB, sukrosa dan bubuk agar dilarutkan dengan akuades dan dididihkan dengan oven hingga terlarut sempurna. Pewarna merah Congo ditempatkan pada wadah tersendiri dan diautoklaf secara terpisah dengan larutan media agar. Pewarna merah Congo akan dicampurkan dengan media agar setelah selesai diautoklaf dan suhu larutan media agar $\pm 80^{\circ} \mathrm{C}$. Setelah tercampur dengan pewarna merah Congo, media agar sebanyak $15 \mathrm{~mL}$ dituangkan ke dalam cawan petri steril.

\section{Peremajaan bakteri uji}

Meremajakan isolat bakteri $S$. epidermidis, $S$. aureus (MSSA 1 dan MSSA 2), MRSA 1 dan E. coli (S4 dan S55) pada media NA (Nutrient Agar) dengan cara memindahkan koloni bakteri tersebut pada media NA miring yang baru kemudian diinkubasi selama 24 jam pada inkubator dengan suhu $37^{\circ} \mathrm{C}$

\section{Uji pembentukan slime bakteri dengan Metode Congo Red Agar (CRA)}

Menanam isolat bakteri $S$. epidermidis, S. aureus (MSSA 1 dan MSSA 2), MRSA 1 dan E. coli (S4 dan S55) yang telah diremajakan diinokulasi ke media CRA dalam cawan petri dengan metode streak 4 area. Menginkubasi selama 24 jam pada suhu $37^{\circ} \mathrm{C}$ pada kondisi aerobik. Produksi slime secara kualitatif diukur berdasarkan warna koloni bakteri yang tumbuh pada media CRA. Interpretasi hasil menurut ketentuan sebagai berikut: Strain menghasilkan koloni warna hitam pekat, hitam, dan hitam kemerahan dianggap memproduksi slime, sedangkan koloni merah dan kemerahan diklasifikasikan sebagai tidak memproduksi slime.

\section{HASIL DAN PEMBAHASAN}

Penelitian ini dilakukan di
Laboratorium Gastroentritis dan
Salmonellosis, Institute of Tropical
Disease (ITD) Universitas Airlangga
Surabaya untuk mengetahui kemampuan
pembentukan biofilm isolat bakteri S.
epidermidis, S. aureus (MSSA 1 dan
MSSA 2), MRSA 1 dan E. coli (S4 dan
S55) dengan metode CRA.

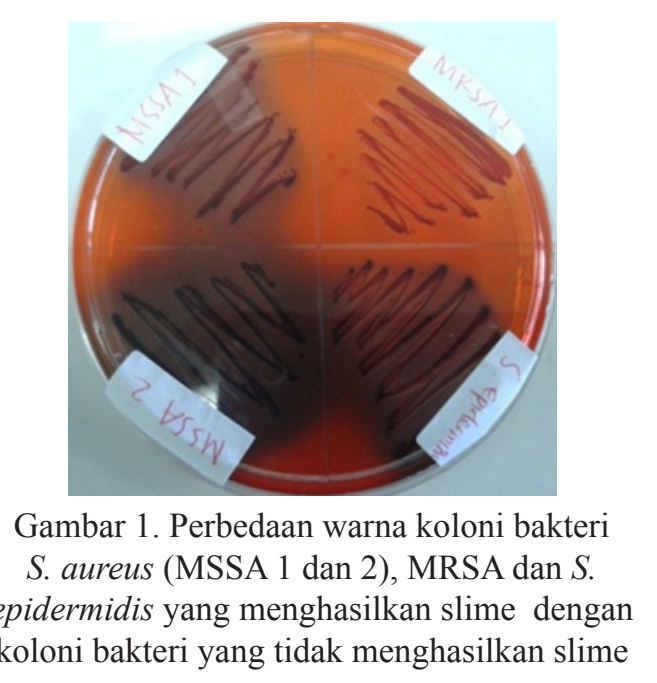




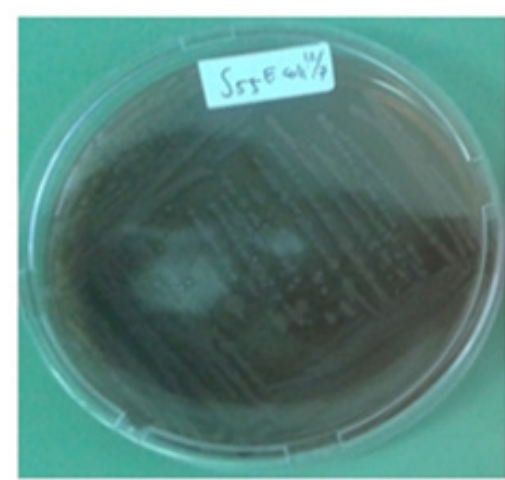

Gambar 2. Warna koloni bakteri E.coli yang menghasilkan slime

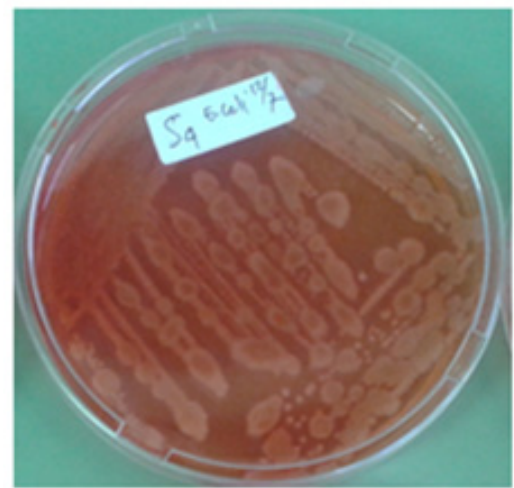

Gambar 3. Warna koloni bakteri E.coli yang tidak menghasilkan slime

Penentuankemampuanpembentukan biofilm dilakukan melalui analisis secara kualitatif dengan mengamati karakteristik morfologi koloni yaitu warna koloni bakteri yang ditumbuhkan pada media CRA. Perbedaan warna koloni bakteri S. aureus (MSSA 1 dan 2), MRSA dan $S$. epidermidis yang menghasilkan slime dengan koloni bakteri yang tidak menghasilkan slime ditunjukkan pada Gambar 1 di bawah ini.

Perbedaan warna koloni bakteri $E$. coli yang menghasilkan slime (Gambar 2) dan yang tidak menghasilkan slime (Gambar 3). Karakteristik morfologi koloni pada bakteri S. epidermidis, MSSA 1, MSSA 2, MRSA 1 dan E. coli pada metode CRA ditunjukkan pada Tabel 1.

Tabel 1. Hasil uji pembentukan slime pada bakteri S. epidermidis, S. aureus dan E. coli dengan metode CRA

\begin{tabular}{|c|c|c|c|c|c|}
\hline \multirow[b]{2}{*}{ Isolat bakteri } & \multicolumn{4}{|c|}{ Karakteristik morfologi koloni } & \multirow[b]{2}{*}{ Hasil } \\
\hline & Merah & $\begin{array}{c}\text { Merah } \\
\text { kehitaman }\end{array}$ & Hitam & Sangat hitam & \\
\hline MSSA 1 & & & $\mathrm{x}$ & & Positif $(+)$ \\
\hline MSSA 2 & & $\mathrm{x}$ & & & Positif $(+)$ \\
\hline MRSA 1 & & $\mathrm{x}$ & & & Positif $(+)$ \\
\hline S. epidermidis & & & $\mathrm{x}$ & & Positif $(+)$ \\
\hline E. coli $(\mathrm{S} 4)$ & $\mathrm{x}$ & & & & Negatif (-) \\
\hline E. coli $(\mathrm{S} 55)$ & & & & $\mathrm{x}$ & Positif $(+)$ \\
\hline
\end{tabular}

Biofilm merupakan komunitas terstruktur dari sel bakteri yang tertutup dalam matriks polimer yang diproduksi sendiri dan melekat pada permukaan inert atau permukaan hidup (Pihl, M. 2011). Infeksi yang disertai dengan pembentukan biofilm menjadi masalah yang besar, karena sulit ditangani secara efektif oleh sistem kekebalan tubuh inang dan tahan terhadap pengobatan dengan antimikroba.
(Cavaliere, et al., 2014). S. epidermidis dan $S$. aureus merupakan penyebab yang paling sering dari infeksi nosokomial dan infeksi pada peralatan kedokteran yang ditanam dalam tubuh, yang memiliki karakterisrik khas seperti mampu membentuk biofilm (Otto, M., 2009).

Sejumlah infeksi yang diakibatkan oleh bakteri gram positif, termasuk yang disebabkan oleh $S$. epidermidis, $S$. aureus 
dan Enterococci terbukti sangat sulit untuk diobati dengan dengan terapi antibiotik yang ada sebagian karena tingkat resistensi alami mereka yang sangat tinggi dan sebagian karena mereka membentuk biofilm. (O'Toole et al., 2000).

Produksi slime dikarakterisasi melalui munculnya pigmen hitam pada media CRA. Strain bakteri yang menghasilkan koloni warna hitam pekat, hitam, dan hitam kemerahan dengan konsistensi kasar, kering, dan kristal dianggap menghasilkan slime, sedangkan koloni merah dan Bordeaux merah dengan konsistensi koloni halus diklasifikasikan sebagai tidak menghasilkan slime. Hasil penelitian ini menunjukkan bahwa melalui metode CRA diketahui bahwa semua Staphylococcus sp. yang di uji (isolat MSSA 1, MSSA 2 dan MRSA 1) mampu membentuk slime yang merupakan komponen dari biofilm. Namun pada isolat $E$. coli, terdapat isolat yang mampu membentuk biofilm dan ada isolat yang tidak mampu membentuk biofilm. Produksi slime menggambarkan kemampuan bakteri untuk melekat secara spesifik pada jaringan host, yang kemudian dilanjutkan dengan produksi mikrokoloni yang invasif. Namun, bila ada beberapa strain bakteri yang tidak mampu membentuk slime dalam suatu jenis bakteri pembentuk slime, hal tersebut menunjukkan bahwa ada variasi ekspresi fenotip dari biofilm atau produksi slime dari suatu jenis bakteri (Dadawala, 2010).

Hasil penelitian ini senada dengan penelitian yang dilakukan oleh Moghadam, Pourmand dan Aminharati, 2014 menunjukkan bahwa sekitar 97,5\% MRSA mampu membentuk slime dan 60\% MSSA mampu membentuk slime pada media CRA. Gowrishhanker et al., 2016 dalam penelitiannya menunjukkan bahwa dari total 63 isolat MRSA yang diuji terdapat $49(77,8 \%)$ isolat yang diketahui positif membentuk slime pada media CRA. Namun pada penelitian Terki et al.,
2013 menunjukkan bahwa hanya sekitar $41 \%$ atau 18/44 dari isolat Staphylococcus sp. yang mampu membentuk slime pada media CRA.

Beberapa penelitian tentang kemampuan $S$. epidermidis dalam membentuk slime juga telah dipublikasikan diantaranya oleh Los et al., 2010, dari total 146 strain $S$. epidermidis yang diisolasi dari bagian nasofaring pada pasien kanker paru-paru terdapat 58,9\% isolat menunjukkan fenotipe positif membentuk melalui uji CRA. Produksi slime tampaknya menjadi mekanisme adhesi yang sangat penting terhadap biomaterial. Penelitian terbaru saat ini menunjukkan bahwa $S$. epidermidis diketahui sebagai penyebab utama infeksi pemakaian kateter. Penelitian terkait pembentukan biofilm menunjukkan bahwa akumulasi slime dimediasi oleh gen ica, yang terdiri dari empat gen adhesi interselular (ica A, ica B, ica $C$ dan ica D) dan satu gen regulator (ica R). Selain itu, hasil penelitian Zhou et al., 2013 menunjukkan hal yang serupa dengan literatur sebelumnya, di mana persentase strain penghasil slime $S$. epidermidis berkisar antara 31\% sampai 89\%. Diantara strain $S$. aureus dan $S$. epidermidis yang didapatkan dari 50 pasien penderita tukak kaki akibat diabetes, didapatkan 55 strain $S$. aureus, 69\% memproduksi slime sementara, dari 20 strain $S$. epidermidis, $75 \%$ yang positif membentuk slime dengan metode CRA (Podbielska et al., 2010).

Tidak berbeda dengan $S$. aureus, pada $S$. epidermidis beberapa penelitian juga menunjukkan hal yang sama bahwa $S$. epidermidis mampu membentuk slime melalui metode CRA. Seperti yang ditunjukkan pada penelitian Nachammai, Karthika Jayakumar, dan Aravazhi, 2016, dari total 100 isolat $E$. coli yang didapatkan dari 400 sampel, terdapat sekitar $70 \%$ isolat yang positif membentuk biofilm melalui metode CRA. Pada penelitian Dadawala, 2010, dari total 14 E. coli isolates yang diuji kemampuannya untuk 
memproduksi biofilm melalui produksi slime pada CRA menunjukkan bahwa 12 isolat mampu memproduksi slime dengan indikasi warna koloni hitam. Observasi produksi slime pada $E$. coli hampir sama seperti penemuan-penemuan sebelumnya sehingga metode ini dapat digunakan sebagai penilaian secara kualitatif terhadap kemampuan produksi biofilm.

\section{SIMPULAN}

Berdasarkan penelitian yang dilakukan dapat disimpulkan bahwa isolat bakteri $S$. epidermidis, $S$. aureus dan MRSA dengan metode CRA (Congo Red Agar) diketahui mampu membentuk slime sedangkan isolat bakteri $E$. coli menunjukkan hasil yang bervariasi.

\section{DAFTAR PUSTAKA}

Cavaliere, R., Ball, J.L., Turnbull, L. and Whitchurch, C.B. 2014. The biofilm matrix destabilizers, EDTA and DNaseI, enhance the susceptibility of nontypeable Hemophilus influenza biofilms to treatment with ampicillin and ciprofloxacin. Microbiology Open. 2014; 3(4): 557-567

Croxen, MA., Robyn J. Law, Roland Scholz, Kristie M. Keeney, Marta Wlodarska, B. Brett Finlay. 2013. Recent Advances in Understanding Enteric Pathogenic Escherichia coli. Clinical Microbiology Reviews p. 822-880 October 2013 Volume 26 Number 4

Dadawala, A.I., Chauhan H.C., Chandel, B.S., Ranaware, P., Patel Sandip S, Khushboo Singh, Rathod P.H., Shah N.M. and Kher, H.N. Assessment of Escherichia coli isolates for In vitro biofilm production. Veterinary World, Vol.3 No.8 August 2010

Daniela Chessa, Giulia Ganau, Vittorio Mazzarello. 2015. Review:An overview of Staphylococcus epidermidis and Staphylococcus aureus with a focus on developing countries. J Infect Dev Ctries 2015; 9(6):547-550. doi:10.3855/jidc.6923

Daniel Lo'pez, Hera Vlamakis, and Roberto Kolter. 2010. Biofilms. Additional Perspectives on Cell Biology of Bacteria. Cold Spring Harbor Laboratory Press. available at www.cshperspectives.org

Decho, A.W., 2011. Extracellular Polymeric Substances (EPS) Encyclopedia of Geobiology. Part of the series Encyclopedia of Earth Sciences Series pp 359-362

Echols RM, Tosiello RL, Haverstock DC, Tice AD. 1999. Demographic, clinical and treatment parameters influencing the outcome of acute cystitis. Clin Infect Dis 1999;29:1139.

Freeman DJ, Falkiner FR, Keane CT. New method for detecting slime production by coagulase negative staphylococci. J Clin Pathol. 1989;42:872-874. [PMC free article]

Ghafourian, S., Mohebi, R. , Rezaei, M., Raftari, M., Sekawi, Z., Kazemian, H., Mohseni, A.,Karimi, S. and Nourkhoda Sadeghifard1. 2013. Comparative Analysis of Biofilm Development Among MRSA and MSSA Strains. Roumanian Archives of Microbiology and Immunology· June 2013.

https://www.researchgate.net/ publication/237146300

Gowrishanka, S., Arumugam Kamaladevi, Krishnaswamy Balamurugan, and Shunmugiah Karutha Pandian. 2016. In Vitro and In Vivo Biofilm Characterization of MethicillinResistant Staphylococcus aureus from Patients Associated with Pharyngitis Infection Hindawi Publishing Corporation BioMed Research International Volume 2016 , 
Jafari A., MM Aslani, dan S Bouzari. 2012. Escherichia coli: a brief review of diarrheagenic pathotypes and their role in diarrheal diseases in Iran. Iran J Microbiol. 2012 Sep; 4(3): 102-117

Kaiser TDL, Pereira EM, Santos KRN, Maciel ELN , Schuenck RP, Nunes APF. 2013. Modification of the Congo red agar method to detect biofilm production by Staphylococcus epidermidis. Diagnostic Microbiology and Infectious Disease 75 (2013) 235239

Klein, MHF., Mário Junior Caizer Santos, Raphael Contelli Klein, Guilherme Nunes de Souza, and Andrea de Oliveira Barros Ribon. 2015. An association between milk and slime increases biofilm production by bovine Staphylococcus aureus. BMC Vet Res. 2015; 11: 3.

Los, R., Rafal Sawicki, Marek Juda, Magdalena Stankevic, Pawel Rybojad,Marek Sawicki,Anna Malm \& Grazyna Ginalska. 2010. Research Lettre:Acomparative analysis of phenotypic and genotypicmethods for the determination of the bioclmforming abilities of Staphylococcus epidermidis

Lebeaux, D., Chauhan A., Rendueles O., and Beloin C. 2013. Review From in vitro to in vivo Models of Bacterial Biofilm-Related Infections Pathogens 2013， 2, 288-356; doi:10.3390/pathogens2020288 pathogens

Moghadam, S.O., Pourmand, M.R., and Aminharati, F. 2014. Biofilm formation and antimicrobial resistance in methicillin-resistant Staphylococcus aureus isolated from burn patients, Iran.

Nachammai S. M., K. Jayakumar, Anbu N. Aravazhi1. 2016. Original Research Article: The effectiveness of antibiotics against a major uropathogen- Escherichia coli and its biofilm assay by phenotypic methods . Int J Res Med Sci. 2016 Nov;4(11):4820-4828

O'Toole, G., Heidi, B., Kaplan, H.B., and Kolter, R. 2000. Biofilm Formation As Microbial as Microbial Development. Annu. Rev. Microbiol. 2000. 54:49-79.

Otto, M. 2008. Staphylococcal Biofilms. Curr Top Microbiol Immunol. 2008 ; 322: 207-228

Pihl, M. 2011. Microbial Biofilms on Peritoneal Dialysis Catheters. Doctoral Dissertation in Odontology. Malmo University

Podbielska A1, Galkowska H, Stelmach E, Mlynarczyk G, Olszewski WL. 2010. Slime production by Staphylococcus aureus and Staphylococcus epidermidis strains isolated from patients with diabetic foot ulcers. Arch Immunol Ther Exp (Warsz). 2010 Aug;58(4):321-4. doi: 10.1007/s00005-010-0079-9. Epub 2010 May 26.

Steinmetz I, Rohde M, Brenneke B. 1995. Purification and characterization of exopolysaccharide of Burkholderia (Pseudomonas) pseudomallei. Infection Immunity. 63(10): 39593965

Terki, K., Hassaine, H., Oufrid, S., Bellifa, S., Mhamedi, I., Lachachi, M. and Timinouni M. 2013. Detection of ica $A$ and ica $D$ genes and biofilm formation in Staphylococcus spp. isolated from urinary catheters at the University Hospital of Tlemcen (Algeria). African Journal of Microbiology Research Vol. 7(47), pp. 5350- 5357-5357. http://www. academicjournals.org/AJMR

Tenke P, Koves B, Nagy K, Uehara S, Kumon H, J Hultgren SJ , Hung C and Mendling W. 2011. Biofilm and Urogenital Infections. Chapter 9. Open Access. 
Tong SYC, Joshua S. Davis, Emily Eichenberger, Thomas L. Holland, Vance G. Fowler, Jr.. 2015. Staphylococcus aureus Infections: Epidemiology, Pathophysiology, Clinical Manifestations, and Management. Clinical Microbiology Reviews July 2015 Volume 28 Number 3
Zhou S., Chao, X., Fei,M. Dai, Y. and Bao Liu 2013. Analysis of S. Epidermidis icaA and icaD genes by polymerase chain reaction and slime production: a case control study. BMC Infect Dis. 2013; 13: 242. 